\title{
Loan Repayment Performance of Micro and Small Enterprises: Evidence from Somali Region, Ethiopia
}

\author{
Yitbarek Kiros \\ College of Business and Economics, JigJiga University, JigJiga, Ethiopia
}

\begin{abstract}
Viable Micro Finance Institutions (MFIs) that reach large number of poor people who are not served by the formal financial institutions have been a prime element for growth of Ethiopia. To operate successfully MFIs have to make sure that loan they disburse have to be repaid back so as to have financially sustainable and viable operation and contribute its own share in poverty reduction of the country. In light of this, this research study was carried to investigate the factors affecting loan settlement of Micro and Small Enterprises(MSEs) financed by Somali Microfinance institution taking lender characteristics in to consideration. Both primary and secondary data was employed used. The primary data was collected by distributing questionnaire and through interview. A total of 175 Micro and Small Enterprises (MSEs) were selected using purposive sampling technique. The secondary data was acquired from various issues of annual reports of Somali Micro Finance institution and other concerned institutions. Both descriptive analysis and econometric model (binary logistic regression) was employed to analyze the effect of the literature driven variables on loan repayment (dependent variable) by borrowers. The binary logistic regression result revealed that among the variables hypothesized to affect loan repayment period, grace period, and timeliness of loan release have statistically significant effect on loan repayment by the borrowers Whereas loan size have statistically insignificant effect on loan repayment performance by the borrowers.
\end{abstract}

Keywords: Loan Repayment Performance, MSEs, MFI, Logistic Regression, Somali Microfinance

DOI: $10.7176 /$ DCS10-9-01

Publication date:September $30^{\text {th }} 2020$

\section{Introduction}

Well-functioning and organized financial markets are pre-requisites for sustainable development. But such markets are often lacking in developing countries (Guush, 2004). The poor are usually excluded from credit facilities because of many reasons. These include insufficient collateral to support their loans, high transaction costs, unstable income, lower literacy and high monitoring costs (Mead \& Liedholm, 1998). The term "microfinance" became widespread and widely used with the formation of Grameen Bank by Muhammad Yunus in the 1970s (Mokhtar, Nartea, \& Gan, 2012). Microfinance institutions were established to fill the gap in the financial sector by providing funds to the lower income society which are usually involved in small and micro business activities. The MFIs provide funds for start-up business or for working capital purpose such as to buy raw materials, machine and business equipment. Majorities of MFIs are from semi-formal institutions and informal institutions that are not profit-oriented organization. Usually they receive funds from government, local government and donors to run their activities. In most poor or developing countries the objective of Microfinance Institutions (MFIs) has been twofold: reducing the risk of income shocks to help reduce poverty and raising asset accumulation to encourage private activity (Armendáriz \& Gollier, 2000).

Since the 1970s, different lending programs have been promoted in many developing countries around the world One of the most common and widely accepted way of addressing the financial need of the active poor in most developed and developing countries, is through Micro, and Small Enterprises (MSEs). MSEs by virtue of their size, location, capital investment and their capacity to generate greater employment have proved their paramount effect on rapid economic growth (MTI, 1997). The sector is also known in bringing economic transition by effectively using the skill and talent of the people without requesting high-level training, much capital and sophisticated technology. Due to these MSEs are recognized as an engine of economic growth and technological progress (Carrier, 1994; Mulharn, 1995). Additionally, micro and small enterprises (MSEs) have been recognized as a major source of employment and income in many countries of the third World (Mead \& Liedholm, 1998). The World Bank claims that between one third and three quarters of total employment in most developing countries comes from informal sector (Norhaziah \& Mohdnoor, 2010). The main methodology of the microfinance institutions in extending finance to the active poor is by disbursing loan to Micro and Small Enterprises (MSEs). It is important to note, however that loan repayment problems are becoming the main obstacle for the MSEs and particularly for MFIs (Norhaziah \& Mohdnoor, 2010). Repayment performance refers to the total loans paid on time as stated in the loan agreement contract. Godquin (2004) defines repayment performance in terms of binary variable; based on an arbitrary definition of what constitutes repaying on time given that maximum grace period is offered. Hence, loan repayment problem is one of the major issues of MFIs that concerns many stakeholders were the high loan default rate is the primary cause for the failure of MFIs. Somali Microfinance Institution (SMFI) was founded in January 31, 2011 registered by the National Bank of Ethiopia according to proclamation No. 
626/2009, and on December 2011 started operations. It has been 6 years since SMFI began providing financial services to the poor of the region. The Institution has been giving the services through its 24 branches. In the year 2016 alone, the institution has made a total amount of loan disbursement of 55,751,550.71 Birr to nearly 311 Micro and Small Enterprises (MSEs) operating in Somali Regional State of Ethiopia. Out of which, 21,928,636.07 Birr or $(\mathbf{3 9 . 4 \%})$ of the loan was repaid in full within the given maturity period or within the loan repayment period. But the remaining amount of Birr 33,822,913.93 or $(\mathbf{6 0 . 6 \%})$ of loan is still in default or arrears, implying that MSEs were unable to repay their loan within the loan repayment period maturity period. In terms of MSEs, 208 MSEs were defaulters or unable to repay the loan within the maturity period and the remaining 103 MSEs were non-defaulters or were able to repay the loan within the given loan repayment period. Hence, this research, was designed to investigate the factors affecting loan repayment performance of the micro and small enterprises (MSEs) taking financed by Somali Micro-Finance Institution (SMFI) in Somali regional state of Ethiopia taking lender characteristics in to account.

\section{Evolution of Microfinance}

Traditional banking sector cannot reach millions of poor for whom small loans could make huge differences. There are several reasons for this, most of the poor are rural, and they are much dispersed. They have low education levels, if at all. As a result, administrative cost of supplying loans to the poor population is extremely high. Another issue that makes it difficult to serve these customers through traditional banking is that, the poor does not have any assets to use as collateral. As a result, the poor had access to loans only through local money lenders at exorbitantly high interest rates. Microcredit financing starts with the assumption that the poor is willing to pay high interest rates to have access to finance. In general, the system uses social trust as collateral. Loans are given to individuals, but an entire group is responsible for the repayment. Hence, the borrower who does not fulfill his or her commitment to repay back will lose his or her social capital. Microcredit institutions report that their repayment rates are above the commercial repayment rates, some times as high as $97 \%$. Today, there are millions of poor people around the world who turn to be entrepreneurs through the microcredit sector (Alemayehu, 2008).

The year 1974 is a landmark in the history of microfinance development. It was by then Professor Muhammad Yunus, a Bangladeshi economist and Noble prize winner who introduced the idea of providing the poor with small loans. While he was on a field trip to an impoverished village with his students, he met a woman and interviewed her. She was making a living from the sale of stool, a kind of small chair (prepared from bamboo). From the interview he conducted with the woman he understood that the woman was making only a penny margin of profit for each stool. Then, he reasoned that the woman would raise herself above subsistence level if she were given the loan with a more advantageous rate: then, he did it from his own pocket. In 1983 he formally established the Grameen bank (meaning-village bank). Thus, the limitations of financial institutions in providing the poor with credit have become the driving forces behind the emergence of MFIs. Nowadays, microfinance institutions are growing to provide the poor with financial as well as technical assistance. The accomplishment of MFIs is, therefore, a manifestation of a paradigm shift that defeated the old notion that the poor are not creditworthy (Bamlaku, 2006). Generally, the field of microfinance was pioneered by specialized non-governmental organizations (NGOs) and banks. They challenged the conventional wisdom of the 1970s and discovered that with new lending methods, the rural poor repaid loans on time. These new methods included providing very small loans without collateral at full-cost interest rates that were repayable in frequent installments. They demonstrated that the poor majority, who are generally excluded from the formal financial sector, can, in fact, be a market niche for innovative banking services that are commercially sustainable. As a result, current microfinance has made a major shift from subsidized microfinance projects of the past, which ended up serving few people, to the development of sustainable financial institutions specialized in serving the low income market. Today there are a growing number of successful microfinance institutions (MFIs) worldwide. These are primarily local institutions that are reaching a significant number of poor people and are becoming commercially viable.

\subsection{History of MFIs in Ethiopia}

The Ethiopian economy has been state controlled through a series of industrial development plans since the Imperial Government of Haile Selassie. Under the state of socialism (1974-91), popularly referred to in Ethiopia as the "Derg regime", financial institutions were directed to finance some public projects that may not have passed proper financial appraisal (Yesuf, 2010). Following the political changes in 1991, a subsequent policy changes has been made towards a free market economy, agriculture focused development and to liberalize the financial sector. To this effect, Proclamation No. 84/94 was issued, which allows private domestic investors to participate in banking and insurance activities, which were previously monopolized by the government. However, the issuance of this proclamation alone did not totally solve the financial problem of the economically active poor people in rural and urban areas (Seifu, 2002). Thus, provision of financial services to the poor has been going on for several years by projects designed by government ministries, departments and non-governmental organizations. Micro credit started as a government and non-government organizations following the 1984/85 severe drought and famine, 
many NGOs started to provide microcredit along with their relief activities although this was on a limited scale and not in a sustained manner (IFAD, 2001). The Government also sporadically provided loans largely for the purchase of oxen through its rural finance department of the Ministry of Agriculture and Cooperatives. But these loans were not based on proper needs assessment and no mechanism was in place to monitor their effectiveness. In many cases, these loans were not repaid and might have fostered a culture of not repaying loans (Getachew \& Yishak, 2005). During the command economy system, the Development Bank of Ethiopia (DBE) and the Commercial Bank of Ethiopia (CBE) were also involved in extending loans to cooperatives largely in response to the government's pressure. A massive default by the cooperatives following the fall of the command economy along with its extensive control systems, however, has forced the CBE to continue to provide loans for the purchase of fertilizers and improved seeds on the basis of regional government guarantees. The DBE has also been providing loans to micro and small scale operators in some selected towns. This scheme was, however, based on donors fund designed in the form of revolving fund, and essentially based on a limited scale in terms of the number of clients covered. Funds were simply given from the DBE to clients identified and screened by the Trade and Industry Bureau of regional governments and this led to a low loan recovery rate (DBE, 1999). The Development Bank of Ethiopia, in collaboration with the Ministry of Trade, has launched a Micro Enterprise Lending Program (MELP). Since 1994, recognizing the importance of microfinance facility, the present government issued a proclamation that laid down the legal framework for licensing and supervision of the business of microfinance institutions (MFIs) in July 1996, through Proclamation No. 40/1996. The objectives of the proclamation were:-

* To provide a legal framework that brings the activities of MFIs within Ethiopia's monetary and financial policies.

$\$$ To provide a legal framework for the promotion of MFIs.

The licensing and supervision of MFIs enhanced the status of MFIs as it authorized them to, among many other things, legally accept deposits from general public (hence diversify their sources of fund), draw and accept deposits, and manage funds for microfinance businesses (Micha'el, 1996). Currently there are total of 39 microfinance institutions (MFIs) in Ethiopia, licensed and registered by NBE, following the issuance of proclamation No. 40/1996with a total capital of ETB 9 billion (EUR 340 million) and is reported that there are approximately 800,000 MSEs across the country. MFIs currently serve over 11 million clients all over the country. As of June 2016, the total outstanding credit and total savings stood at ETB 25 billion (EUR 944 million) and ETB 18 billion (EUR 680 million) respectively. Regarding interest rate charged by the MFIs in the Ethiopia, it is very low in comparison to other African countries and they hardly allow the MFIs to achieve operational selfsufficiency. In fact, Ethiopian MFIs have string social mission because of their ownership structure with heavy focus on poverty alleviation and increased client outreach. If MFIs want poor people to have access to credit services, they have to integrate financial services with non-financial services such as training, business development services and counseling, in order to help poor clients become good and responsible entrepreneurs. This, however, is a cost-push factor affecting the self-sustainability of MFIs. Many experts and observers consider operational and financial self-sustainability as a prerequisite for a sound development of microfinance. Accordingly, they strongly recommend further developments aimed at increasing attractiveness of the microfinance sector to private investment. Whatever the case may be MFIs should not lose their original vision that is serving as a stepping stone to a better life for the poor by allowing the poor section of the society to have.

\section{Overview of MSEs in Ethiopia}

In developing countries, Micro, Small and Medium Enterprises (MSEs) by virtue of their size, location, capital investment and their capacity to generate greater employment have proved their paramount effect on rapid economic growth (MTI, 1997). The sector is also known in bringing economic transition by effectively using the skill and talent of the people without requesting high-level training, much capital and sophisticated technology. Due to these MSMEs are recognized as an appropriate means of economic growth and technological progress (Carrier, 1994; Mulharn, 1995). Moreover, MSEs exert a very strong influence on the economic growth of all countries over the world (Aharoni, 1994; Drillhon \& Estime, 1994). The MSEs sector is also described as the natural home of entrepreneurship since it provides an ideal environment that enable entrepreneurs to exercise their talents to fill and attain their goals. The MSMEs sector is seen as an essential catalyst for job creation, unemployment reduction and social progress at large since it takes the lion share of fast growing labor force in the world particularly 48\% in North Africa, 51\% in Latin America, 65\% in Asia, and 72\% in Sub-Saharan African Countries (ILO, 2002). The study made in five countries of Eastern and Southern Africa (Botswana, Kenya, Malawi, Swizaland \& Zimbabwe) by Mead and Liedholm (1998), shows that people engaged in MSES are nearly twice the level of employment in large scale enterprises and in the public sectors. In Ethiopia Microfinance sector is the second largest employment generating sector next to agriculture. It is with this conjuncture that the Ethiopia government of has prepared a full-fledged MSEs development strategy and was formulated in 1997 and institutionalized a year later by the establishment of the Federal Micro and Small-Scale Enterprise Development Agency (FeMSEDA) and Regional Micro and Small-Scale Enterprises Development Agencies (ReMSEDAs). The 
strategy was revised in 2011 with renewed interest and far more ambitious targets (FDRE, 2011). The strategy has been translated into medium term development plans and due attention is given to its implementation. For example, in the first growth and transformation plan (GTP) (2010/11-2014/15), the country had the target to create about 3 million jobs through the promotion of MSEs (MoFED, 2010). At the end of GTP I and on the eve of GTP II, the government of Ethiopia had reported that about 7 million permanent and temporary jobs had been created by MSEs (NPC, 2015 \& FeMSEDA, 2016).

\subsection{Definition of MSEs in Ethiopia}

MSEs can be defined based on various criteria such as employment size, total asset, revenues/sales, to distinguish as micro and small enterprises in different countries. In the case of Ethiopia, paid up capital and number of employees are used to define MSEs. According to the revised micro and small development strategy, 2011, the revised definition considers employed labor force including family labor; total assets without working building and the division of sub sector in to services and manufacturing are the main criteria.

\section{Definition of Micro Enterprises}

Enterprises employing up to 5 person including owners and family members and with total assets of not more than ETB 100,000 (USD 4, 6303).

$\$$ For the industrial sector (including manufacturing, construction and mining): Enterprises employing a maximum of five persons, including the enterprise owners and family members, with a total asset of not more than ETB 100,000 (USD 4,630).

$\$$ For the service sector (retail trade, transport, hotel, tourism, and information technology and maintenance services): Enterprises employing a maximum of five persons, including the enterprise owners and family members, with a total asset of not more than ETB 50,000 (USD 2,310).

\section{Definition of Small Enterprises}

For the industrial sector (manufacturing, construction and mining): This refers to enterprises employing 6-30 persons and with a total asset of from ETB 100,001 up to ETB 1,500,000 (USD 4,630 up to USD 69,500); and for the service sector (retail trade, transport, hotel, tourism, and information technology and maintenance services): This refers to enterprises that are employing 6-30 persons, and with total asset of at least ETB 50,001 and up to ETB 500,000 (USD 2,310 up to USD 23,150).

Table 1: Revised Definition of MSEs (Ethiopia)

\begin{tabular}{lccc}
\hline Level Enterprise & Sector & Human Power & Total Asset \\
Micro Enterprise & Industry & $\leq 5$ & $\leq 100000(\$ 6000$ or Euro 4500) \\
& Service & $\leq 5$ & $\leq 50,000(\$ 3000$ or Euro 2200) \\
Small Enterprise & Industry & $6-30$ & $\leq$ birr 1.5 million $(\$ 9000$ or Euro 70000$)$ \\
& Service & $6-30$ & $\leq$ birr 500,000(\$30000 or Euro 23000) \\
\hline
\end{tabular}

\section{Literature Review on Loan Repayment}

\subsection{Empirical Studies on Loan Repayment: Global View}

Bruce and Kofi (1999) conducted a research on the determinants of loan default and delinquency in rural credit programs in Ghana using a logit regression. The study revealed that, a person who is married is less likely to default than one who is separated or divorced. A male is more likely to default than a female. Holding everything else constant, the larger the loan, the less likely a person is to default. Borrowers with an elementary or secondary education are more likely to default compared to those with no formal schooling.

According to Ajayi (1992) the factors which influence loan default in mortgage finance institution with particular reference to the Federal Mortgage Bank of Nigeria using multiple regression analysis based on 128 samples showed that default has largely been positively influenced by cost of construction, monthly repayment, loan to value ratio, market value of property, age of borrower and the annual income of borrower. The expected rental income from property, however, had a negative influence on default. A study made by Njoku and Odii (1999) on the determinants of loan repayment in Nigeria by employing multiple regression model based on 300 sample beneficiaries indicated that poor loan repayment performance was as result of late release of loan funds, cumbersome loan application and disbursement procedures and emphasis on political considerations in loan approvals. In addition, loan diversion to non-agricultural enterprises as well as low enterprise returns resulting from low adoption rate of improved agricultural technologies contributed to poor loan repayment performance of small holders. Loan volume, years of farming experience, farming as major occupation, years of formal education, household size, loan period, farm size, farm output, value of assets and interest paid on loan were all highly significant determinants of loan default. The coefficients of loan volume, years of formal education, household size and interest paid on loan are positive while the coefficients for years of farming experience, loan period, farm size, farming as major occupation, farm output, and value of assets are negative.

Kashuliza, 1993 used a linear regression model to analyze determinants of loan repayment in small holder agriculture in the southern highlands of Tanzania. His study showed that education, attitude towards repayment, 
farm income and off-farm income positively affect loan repayment with farm income being significant, while age, household expenditure and household size have negative influence on loan repayment performance with household expenditure being significant. A study by Ade (1999) on the determinants of small holder loan repayment performance evidence from Nigerian micro-finance system found out that the proportion of borrowers with secondary education, number of times visited by loan officials and the loan size were the major factors that cause the loan default by the borrower.

Vigano (1993) in his study about the case of development bank of Burkina Faso employed a credit-scoring model. He found out that being women, married, aged, more business experience, value of assets, timeliness of loan release, small periodical repayments, project diversification and being a pre-existing depositor are positively related to loan repayment performance. On the other hand, loan in kind, smaller loan than required, long waiting period from application to loan release and availability of other source of credit were found to have negative relation with loan repayment performance. In an attempt to empirically analyze the loan repayment determinants in micro enterprises in Madagascar, (Zeller 1996), employed a Tobit model using information obtained at the household, group and community level. The result based on 146 sample groups showed that enterprises with higher levels of social cohesion have a better repayment rate. The result also lead to the conclusion that it is not the level of physical and human assets of the enterprises but the degree of variance of risky assets among members that contributes to better loan repayment. The result therefore indicated that heterogeneity in asset holdings among members and related intra group diversification in on and off farm enterprises, enables members to pool risks so as to better secure repayment of the loan. Furthermore, gains in the repayment rate due to risk pooling diminish at the margin because of increased costs of coordination, monitoring, and moral hazard that come with greater heterogeneity in groups.

(Von Pischke 1991), in his explanation about the cause of poor loan collection performance by formal agricultural lenders in developing countries, attributed to general conditions of low levels of economic development. Farm level causes of loan arrears as cited by him include small farmers' poverty, large farmers' political influence, low returns and lack of profitable innovation in tropical and sub-tropical agriculture, unfamiliarity with modern commercial practice among certain rural societies, cultural factors such as the weakness or absence of moral incentives or small group sanctions for timely repayment, illiteracy, lack of farm planning, insufficient supervision, and low level of formal education achieved by typical borrowers. Problems at the lender side include deficiency in loan administration and lack of market information such as system of credit rating based on repayment performance. In addition, difficulty in enforcing contracts through judicial or administrative law process could be cited as a country level problem constraining lender performance.

(Hunt 1996), examined the credit rationing technology of lenders and the repayment behavior of borrowers at a rural financial institution taking a sample of 504. Loan rationing equation and loan repayment equations estimated employing Tobit model using survey data at Guyana Cooperative Agricultural and Industrial Development Bank revealed that only $33 \%$ of the criteria utilized identified creditworthy borrowers implying that the screening technology was not efficient and needed to be repaired. The results also indicated that tightening the loan contract terms by reducing the grace period on loans and rejecting applications which had long processing times enhanced the pool of credit worthy borrowers. Female borrowers were also not rationed differently than male borrowers nor were they are worse payers than male borrowers (i.e. the variable sex was insignificant), but wealthy borrowers were bad credit risks as their repayment performance is poor. In general, the study showed that only four out of twelve explanatory variables, which are fishing, males in food crops and livestock, credit experience and sugar cane enhance creditworthiness, while other variables especially grace period, delays, and joint borrowers contribute significantly to the default problem. (Okorie 1986), provided empirical evidence and quantification of the extent to which some factors influence loan repayment among smallholder farmers in developing countries with particular reference to small holders farmers in Ondo state of Nigeria based on 45 sample units. Based on obtained result, these factors and their correlation coefficients with their signs are identified as follows: number of disbursement $(+0.372)$, time of disbursement $(+0.658)$, number of supervisory visits by credit officers after disbursement $(+0.411)$ and the profitability of enterprise on which loan funds were invested $(+0.309)$. Arene (1992) in an attempt to evaluate the credit delivery system of Supervised Agricultural Credit Schemes among small holder farmers in Anambra State of Nigeria with emphasis on loan repayment rate conducted a multiple regression analysis. The result is based on 95 sample farmers showed that timely loan repaying farmers had larger loan size, larger farm size, higher income, higher age, higher number of years in farming experience, shorter distance between home and source of loan, higher level of formal education, larger household size, higher level of adoption of innovations, and lower credit needs than defaulting farmers. The regression analysis showed that size of loan, farm size, income, age, number of years of farming experience, level of formal education and adoption to innovations are significantly and positively related to repayment rate, but distance between home and source of loan, household size, and credit needs account for less.

Padmanabhan (1981), mentioned some of the specific reasons for default in rural credit projects which a development banker can possibly guard against at the time of project preparation or appraisal based on Indian 
experience. These factors include: under financing, over investment, imperfect analysis, unrealistic repayment schedule, inadequate technical support, improper planning of infrastructural support, ineffective arrangements, inadequate communication between branch office and head office, cursory assessment of response from the farmers, reduction in the unit value of projects and high propensity to consume.

\subsection{Empirical Studies on Loan Repayment: Ethiopian View}

In Ethiopia an econometric estimation was conducted by Mengistu (1997) based on survey data, on the determinants of loan repayment performance and efficacy of screening mechanism in urban Ethiopia, taking the case of Awassa and Bahir-Dar towns. The estimation result using binomial Probit model revealed that for Awassa, the number of persons employed and weekly installment repayment period are significantly and positively related with repaying loan in full while loan diversion is significantly and negatively related. In terms of the probability of falling in either of the groups, it is found that there is $53 \%$ probability of repaying loan in full. In the case of Bahir-Dar, loan expectation and number of workers employed have a positive relation with full loan repayment while loan diversion and availability of other sources of credit have a negative impact. The predicted probability of full loan repayment in this case is $78 \%$. He employed 352 sample beneficiaries for the case of Awassa and 409 for Bahir-Dar.

Berhanu (1999) and Teferri (2000) made an attempt employing a binomial probit model on determinants of loan repayment performance of micro enterprises with particular reference to POCSSBO in Addis Ababa and DECSI in Tigray. Birhanu found out that loan diversion, loan size and monthly income were undermining factors while beneficiaries' age, perceived cost of default and suitability of repayment period were enhancing factors of loan repayment. Based on 2348 sample beneficiaries Teferri also came up with the result that education and size of loan are significant determinants in all the three cases (i.e. urban, rural and all sample beneficiaries) their sign being positive and negative respectively. Other variables such as sex, timeliness of loan disbursement and monthly income are positively and significantly related with loan repayment in rural and whole sample beneficiaries while loan diversion is negatively and significantly related with full loan repayment in urban and whole sample beneficiaries.

In another relevant study by Abraham (2002) an investigation on the determinants of repayment status of borrowers with reference to private borrowers around Zeway area who are financed by the Development Bank of Ethiopia (DBE). The estimation result employing Tobit model revealed that having other source of income education, work experience in related economic activity before the loan and engaging on economic activities other than agriculture are enhancing while loan diversion, being male borrower and giving extended loan repayment period are undermining factors of loan recovery performance.

Bekele (2003) employed a logistic regression model to analyze the factors influencing loan repayment performance of small holders in Ethiopia. The authors used data on 309 borrowers of input loans in the Oromia and Amhara Regional states and found out that individuals who took larger loans had better repayment performances than those who took smaller loans. Further the results of the study revealed that late disbursement of inputs purchased by the loan funds was an important bottleneck in loan repayment while livestock were found to be important in improving the farmers' repayment performance. Mengistu (1999) also made an empirical analysis on the determinants of industrial loan repayment in Ethiopia with particular reference to manufacturing firms in Addis Ababa. The regression result employing Tobit model based on 65 manufacturing firms revealed that total investment cost, ratio of value of collateral to total loan amount, the firm's grace period, number of disbursement installments, and time were statistically insignificant, while repayment period and number of supervision are significantly and positively related to loan recovery rate. However, coefficients of loan amount and ratio of pre-operating interest to total loan amount are significant at $10 \%$ and $5 \%$ respectively and negatively related with loan recovery rate. Therefore, from the above empirical studies conducted in Ethiopia one can understand that most of them focused on identifying the determinants factors that affect the loan repayment performance of micro and small enterprises located inother parts of Ethiopia. Too little has been known about this issue in Somali regional State. However, to the best knowledge of the researcher there is no research conducted that focused on investigating the key determinant factors that affect loan repayment performance of the micro and small enterprises finance by Somali Microfinance Institution (SMFI) in the year 2016.

\section{Conceptual Framework}

Theoretically, loan repayment by the MSEs is subject to different set of dynamic forces which may be either related to lender or borrower characteristics. From the conceptual frame work of the study it can be understood that for loan either to be repaid or to be default that is the lender characteristics, which includes many major factors that can affect the loan either in a positive or negative way. That means loan repayment is a cumulative function of many major lender characteristics or factors. The majior lender factor that are included in this research are four variables which are grace period, timeliness of loan release, loan size, and repayment period, which is the aim and scope of this research and investigate the effect of these factors have on the loan repayment performance by the 
MSEs.

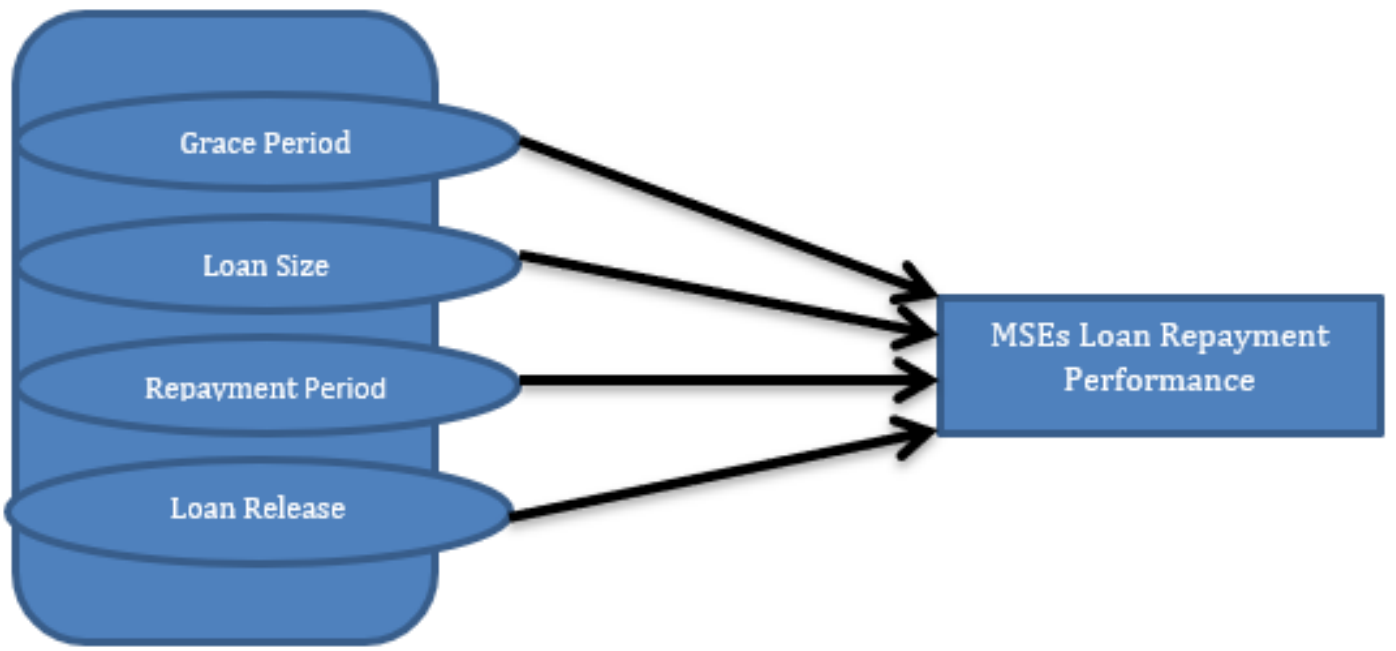

Figure 1: Conceptual Framework

\section{Hypotheses Development}

6.1 Grace Period and Loan Repayment

If large grace period is given, the borrower will have sufficient time for implementation of the loan (project) so that the borrower could properly utilize the loan for the intended purpose and this enables the loan (project) to generate adequate income after it starts operation. Therefore, the borrower will not face repayment problem (Abraham, 2002; Hunt, 1996).

\section{$H_{1:}$ The lager the grace period, the higher the probability of loan repayment by the MSEs.}

\subsection{Timeliness of Loan Release and Loan Repayment}

If loan is disbursed on time, it is unlikely that it will be diverted to non-intended purposes. The complicated appraisal and approval procedures might delay loan disbursement. Further, this could worsen the prospects of loan repayment by diverting loan to non-intended purpose (Berhanu, 1999; Chirwa, 1997; Daba, 2004; Jemal, 2003; Teferi, 2000; Zeller, 1996).

\section{$H_{2:}$ The timely the loan is released, the higher the probability of loan repayment by the MSEs.}

\subsection{Loan Size and Loan Repayment}

This is the amount of loan or money the group has borrowed from the micro finance institution. It is argued that smaller amount of loans are insufficient creating cash flow problems to the borrower thus significantly affecting the project (Roslan \& Mohd, 2009). Furthermore, the bigger the loan, the higher is the penalty cost associated with any delinquency or default and this puts more pressure on the borrower to reduce delinquency or default (Manohar \& Zeller, 1997). Therefore, the larger the loan size, the better loan repayment by the group.

$\mathrm{H}_{3}$ : The larger the loan size, the higher the probability of loan repayment by the MSEs.

\subsection{Repayment Period and Loan Repayment}

Repayment period refers to the time period during which the entire loan must be repaid (Roslan \& Mohd, 2009). If it is relaxed, the amount of each installment required to pay will decrease, the debt burden on the borrower will be smaller hence the borrower will not face any difficulty in properly meeting his or her debt obligations (Abraham, 2002). But in this study, the shorter the repayment period, the better will be the loan repayment by the group. This is because; if the repayment period is longer the borrower might use the funds for other purposes hoping to repay the loan from later cash flows (Roslan \& Mohd, 2009; Njoku \& Odii, 1999; Berhanu, 1999; Teferi, 2000).

\section{$H_{4:}$ The shorter the repayment period, the higher the probability of loan repayment by the MSEs.}

\section{Materials and Methods}

\subsection{Sample Size and Sampling Technique}

To examine the factors affecting the loan repayment of the MSEs, this study draws on empirical evidence from the 2016 survey covering 175 purposively selected MSEs from Somali regional state of Ethiopia. A semistructured questionnaire and interview were used to collect first hand data. The data was analyzed using econometric analysis tool, that is, binary choice logistic regression model was used to test the literature driven hypotheses and to draw conclusions. As per the data obtained from regional bureau of trade and industry, there were 311 Micro and Small Enterprises established and fianced by Somali Microfinance Institution on 2016 E.C in 
the region. Hence, the sample size (n) is determined to be 175 using the scientific formula given by Yamane (1967), in which $e$ is the level of precision i.e., $e=0.05$ (5\% level of significance). The sample size was determined as follows:

Where: $\mathbf{n}=$ Sample Size

$$
\mathbf{n}=\frac{N}{1+N(e)^{2}}
$$

$\mathbf{N}=$ Population Size,

$\boldsymbol{e}=$ is the level of precision i.e., $e=0.05$ ( $95 \%$ level of significance)

$$
\mathrm{n}=\frac{311}{1+311(0.05)^{2}}=175
$$

\subsection{Econometric Model}

In this study MSEs are assumed to be either defaulting or non-defaulting. Hence the binary choice logistic regression model that assumes dichotomous dependent variable which takes either 1 or 0 value depending on $\mathrm{Y}^{*}$ is used

Let $\mathrm{Y}_{\mathrm{i}}=1$, if the borrower repaid the full amount of the loan within the given maturity period.

$\mathrm{Y}_{\mathrm{i}}=0$, if the borrower did not repaid the full amount of the loan within the given maturity period.

But $\mathrm{Y}_{\mathrm{i}}=1$, if $\mathrm{y}^{*}$ is $>0$

$$
\mathrm{Y}_{\mathrm{i}}=0 \text {, if } \mathrm{y}^{*} \text { is } \leq 0
$$

Where $\mathrm{y}^{*}$ is a latent variable. It is undetected factor which can affect the loan repayment by the borrower. Hence it cannot be measured.

The probability that a borrower will repay the loan $\left(\mathrm{P}_{\mathrm{i}}=1\right)$, is given by:

$$
\mathrm{P}_{\mathrm{i}}\left(\mathrm{Y}_{\mathrm{i}}=1\right)=\frac{1}{1+\mathrm{e}^{-\mathrm{zi}}} \quad \text { or } \quad \frac{\mathrm{e}^{\mathrm{z}}}{1+\mathrm{e}^{\mathrm{z}}} \text {-------- Equation } 1
$$

If the probability of repaying the loan is given by equation 1 , then the probability of non-repayment of the loan is: $\mathrm{P}_{\mathrm{i}}\left(\mathrm{Y}_{\mathrm{i}}=0\right)$ is given by $1-\mathrm{Pi}=\frac{1}{1+\mathrm{e}^{\mathrm{zi}}}$. Hence, it can be re-written as:

$$
\frac{1-\mathrm{Pi}}{\mathrm{Pi}}=\frac{1+\mathrm{e}^{\mathrm{zi}}}{1+\mathrm{e}^{-\mathrm{z}}}=\mathrm{e}^{\mathrm{zi}} \text {-------- Equation } 2
$$

Now, $\frac{\mathrm{Pi}}{1-\mathrm{Pi}}$ is simply the odd ratio- the ratio of the probability that the borrower repays the loan to the probability that the borrower does not repay the loan within the given maturity period. Mathematically, the model is specified as follows:-

\begin{tabular}{|c|c|c|c|}
\hline Variables & Code & Variable & Definition of Variable \\
\hline \multicolumn{4}{|c|}{ Dependent Variable } \\
\hline \multirow[t]{2}{*}{ Loan Repayment } & Dummy & $\mathrm{Lr}$ & $\begin{array}{l}0=\text { If loan not fully repaid(Defaulter) } \\
1=\text { If loan fully repaid(Non defaulter) }\end{array}$ \\
\hline & \multicolumn{3}{|c|}{ Independent Variables } \\
\hline Grace period & Dummy & Gp & $\begin{array}{l}0=\text { If grace period is not enough } \\
1=\text { If grace period is enough }\end{array}$ \\
\hline Timeliness of loan release & Dummy & Tlr & $\begin{array}{l}0=\text { If loan is not timely released } \\
1=\text { If loan is timely released }\end{array}$ \\
\hline Loan Size & Continuous & Ls & Measured by the amount of loan taken \\
\hline Repayment Period & Dummy & $\mathrm{Rp}$ & $\begin{array}{l}0=\text { If repayment period is not enough } \\
1=\text { If repayment period is enough }\end{array}$ \\
\hline
\end{tabular}

$$
\mathbf{L R}=\frac{\mathrm{pi}}{1-\mathrm{pi}}=\boldsymbol{\beta}_{0}+\boldsymbol{\beta}_{1} \mathbf{l s}+\boldsymbol{\beta}_{2} \mathrm{tlr}++\boldsymbol{\beta}_{3} \operatorname{lrp}++\boldsymbol{\beta}_{4} \mathrm{gp}+\mathrm{e}_{\mathrm{i}}
$$

Where: $\frac{\mathrm{pi}}{1-\mathrm{pi}}=$ Natural logarithm of the odd ratio (logistic model), which is the marginal effect.

Table 2: Description of Variables

\section{Results and Discussion}

Loan repayment is the dependent variable that measures the loan collection performance of Somali Microfinance Institution (SMFI). Regarding loan repayment, 58.5\% (102) of the respondents were able to repay the loan within the given maturity period. The main reasons the borrowers were:-

\& The business is profitable.

* It is their obligation to repay the loan.

Whereas the remaining $41.5 \%$ (72.6 73) respondents were found to be defaulter. According to the respondents the following are the main reason for their default is that the business is not profitable. As it is well articulated in literatures loan default is critical and affects financial sustainability of MFIs. The high loan default rate might endanger the financial sustainability of SMFI. Therefore, SMFI have to ensure timely repayments of loans tobetter reach out other active poor people in the region. 


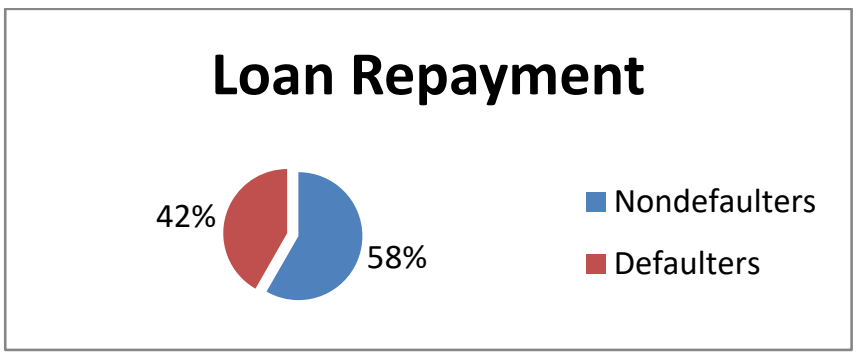

Figure 2: Loan Repayment Performance

\subsection{Grace Period}

It has a positive relation with loan repayment and is statistically significant at $1 \%$ level of significance. The marginal effect of -0.923 implies, holding other variables constant, the probability of repaying the loan decreases by $92.3 \%$ for those borrowers who seek larger grace period as compared to those borrowers who do not seek larger grace period. The possible reasons as to why defaulted borrowers prefer larger grace period is that, with shorter grace period the loan cannot generate enough cash flows to settle the loan within the given repayment period since the project cannot be fully implemented within the given grace period may be due to shortage of working materials and also it might be difficult to find the market and sell the products within the given grace period. This finding opposes the findings of Abraham (2002) and Hunt (1996). However Mengistu (1999) found out that the variable grace period is statistically insignificant factor. Hence the hypothesis "the lager the grace period, the higher the probability of loan repayment by the MSEs" is rejected.

\subsection{Timeliness of Loan Release}

If the loan is released on time it is unlikely that it will be diverted to non-intended purposes. The variable is found to be significant at $10 \%$ level of significance and have positive relationship with loan repayment. The marginal effect of 0.221 implies, the probability of loan repayment increases by $22.1 \%$ for those who have received the loan on time as compared to those borrowers who do not receive the loan on time. This is because, timeliness of loan release is important especially when loans are used for seasonal activities. The complicated appraisal and approval procedures that could delay loan disbursement and influence program of seasonal loans. Further this could in turn worsen the prospect of timely loan repayment. The same result was obtained with the findings of Jemal (2003), Zeller (1996), and Teferi (2000). Hence the hypothesis the timely the loan is released, the higher the probability of loan repayment by the MSEs is accepted.

Table 3: Summary Result of Logit Model

\begin{tabular}{lcccc}
\hline Variables & $\mathbf{Z}$ & $\mathbf{P}>|\mathbf{z}|$ & {$[\mathbf{9 5 \%}$ Conf. Interval] } & dy/dx \\
\hline Repayment Period & 9.36 & $0.000^{* * *}$ & $212757.9-1.4208$ & 0.0148471 \\
Grace Period & -6.11 & $0.000^{* * *}$ & $4.8308-.0001735$ & -0.9233988 \\
Loan Size & -0.14 & 0.891 & $.4231564-2.112241$ & -0.0000502 \\
Timeliness of Loan & 1.68 & $0.094 *$ & $.821324-12.49204$ & 0.2213501 \\
Release & & & & \\
\hline$* * *$ Significant at 1\%, **Significant at 5\%, *Significant at 10\% &
\end{tabular}

$\mathrm{dy} / \mathrm{dx}$ : is a marginal effect after logistic which is discrete change of dummy variable from 0 to 1

\subsection{Repayment Period}

The variable repayment period has a positive relationship with loan repayment and is statistically significant at $1 \%$ level of significance. The marginal effect 0.148 implies the probability of loan repayment decreases by $14.8 \%$ for those borrowers who seek larger repayment period as compared to those who do not seek larger repayment period. The possible reason might be, as repayment period gets longer the probability that the borrower might be tempted to spend the income in the early duration or time of the project resulting in potential struggle to make loan payments during later periods of the project. The result of this study is also alike with the findings of Njoku and Odii (1999), Roslan and Mhod (2009), Berhanu (1999). But it contradicts with the findings of Abraham (2002). Hence, the hypothesis "the shorter the repayment period, the higher the probability of loan repayment by the MSEs" is accepted. 
Table 4: Hypothesis Decision

\begin{tabular}{llll}
\hline No & Variable & P-value & Decision \\
\hline $\mathbf{1}$ & Loan Size & $0.000 * * *$ & Reject Hypothesis \\
$\mathbf{2}$ & Grace Period & $0.037 * *$ & Reject Hypothesis \\
$\mathbf{3}$ & Repayment Period & $0.000 * * *$ & Accept Hypothesis \\
$\mathbf{4}$ & Timeliness of Loan Release & $0.094 *$ & Accept Hypothesis \\
\hline *** & Significant at 1\%, **Significant at $5 \%, *$ Significant at $10 \%$
\end{tabular}

\section{Conclusion}

In developing countries like Ethiopia where unemployment is high, micro and small enterprises have a crucial role in creating jobs. Currently, micro and small enterprises are dominating the business in the urban and areas across the world. However, micro and small enterprises face scarcity of capital to develop to medium and large scale enterprises and contribute to the country's economic development. To tackle the problem of capital deficiency of MSEs, credit is a fundamental part for the development of MSEs sector. However, it is important that borrowed funds must be used for intended purposes and for the financial institutions to run profitable business venture so that MSEs can continue to get sustainable source of finance. In microfinance institutions, there are severe problems of loan default which erodes MFIs liquidity position and there by affecting MFIs financial viability and outreach operation. It is with this intention of identifying the factors that influence loan repayment performance of MSEs financed by SMFI was the primary motive of this research study.

As per this finding of this research work, of 175 Micro and Small Enterprises (MSEs) or borrowers, 10.2.4 102(58.5\%) MSEs were found to be non-defaulters whereas the remaining 73(41.5\%) MSEs were found to be are defaulters. To identify the most important explanatory variables that affect loan repayment performance of the MSEs is conducted using binary logistic regression model. The model reveals that among four explanatory variables which were hypothesized to influence loan repayment, two variables (Repayment Period and Timeliness of loan release) were found to be statistically significant. The remaining two variables (Loan Size and Grace Period) were found to be statistically insignificant in affecting loan repayment performance of the MSE. The two variables are loan size and grace period. Therefore, SMFIs must conduct different capacity building trainings for the MSEs on business skills, provide different BDS (Business Development Service) to the MSEs on how they can manage their business effectively and efficiently as well as SMFI should use or employ some sort technology IT for its loan follow-up system so that it can trace easily the status of each loan.

\section{Reference}

Abraham, G. (2002). Loan repayment and its determinants in small scale enterprises financing in Ethiopia the case of private borrowers around zeway area, (Masters Thesis), Addis Ababa University, Ethiopia.

Ade, S. O. (1999). Determinants of small holder loan repayment performance: Evidence from Nigerian micro Finance system. Savings and Development, 1, 95-108.

Adeno, K. (2007). Outreach and sustainability of the Amhara Credit and Saving Institution (ACSI), (Masters Thesis). Norwegian University of Life Sciences (UMB). Norway.

Adeyemo, R. (1984). Loan delinquency in multi-purpose cooperative Union in Kawara State. Savings and Development, 17 (3).

Ajayi, C. A. (1992). An analysis of default factors in residential mortgages of the federal mortgage bank of Nigeria. African Review of Money, Finance and Banking, 2, 203-215.

Alemayehu, Y. (2008). The performance of micro finance institutions in Ethiopia: A case of six microfinance institutions, (Master Thesis). Addis Ababa University, Ethiopia.

Anna, C. B. \& Heidi, H. O. (2009). Analysis of the determinants of the Nigerian Banking system's profits and profitability performance. Savings and Development, 4, 353-371.

Arene, C. J. (1992). Loan repayment and technical assistance among small holder maize farmers in Nigeria. African Review of Money, Finance and Banking, 1 .

Armendáriz de Aghion, B., \& Gollier, C. (2000). Peer group formation in an adverse selection model. Economic Journal, 110 (01), 632-643.

Armendariz de Aghion, B. (1999). On the design of a credit agreement with peer monitoring. Journal of Development Economics 60 (1): 79-104.

Awoke, M. U. (2004). Factors affecting loan acquisitioned repayment patterns of smallholder in Inlka North-East of Delta state Nigeria. Journal of Sustainable Tropical Agriculture Research, 9, 61-64.

Bamlaku, A. (2006). Micro financing and poverty reduction in Ethiopia: A paper prepared under the Internship Program of IDRC, Nairobi.

Banerjee, A. V., Besley, T., \& Guinnane, T. W. (1994). Thy neighbor's keeper: The design of a credit cooperative with theory and a test. Quarterly Journal of Economics 109 (3): 491-515.

Bekele, T. (2003). Factors influencing loan repayment performance of small holder in Ethiopia, (Masters Thesis), 
Alemaya University, Ethiopia.

Berhanu, L. (1999). Micro enterprises credit and poverty alleviation in Ethiopia: The case of the project office for the creation of small-scale business opportunities in Addis Ababa, (Masters Thesis), Addis Ababa University, Ethiopia.

Besley, T. \& Coate, S. (1995). Group lending, repayment incentives and social collateral. Journal of Development Economics, 46(1), 11-18.

Bhatt, N., \& Tang, S. (2001). Delivering microfinance in developing countries: Controversies and policy perspectives. Policy Studies Journal, 29(2)

Bruce, H. D., \& Kofi, Q. D. (1999). The determinants of loan default and delinquency in rural credit programs in Ghana. Policy Studies Journal, 54(14): 58-73.

Chirwa, E. W. (1997). An econometric analysis of the determinants of agriculture credit payment in Malawi. African Review of Money Finance and Banking, Supplement of the Savings and Development Journal, 1(2), 107-119.

Copisarow, R. (2000). The application of micro credit technology to the UK: Key commercial and policy issues. Journal of Microcredit, 1(1).

Daba, M. (2004). The impact of micro financing on poverty reduction: The case study of Oromia Credit and Saving Share Company (OCSSCO), Paper presented in the International Conference on Micro Finance, January 21-23, 2004, Awassa, Ethiopia.

DBE (Development Bank of Ethiopia). (1999). DBE 1999/2000 loan recovery performance report, Addis Ababa, Ethipoia.

De Soto, H. (2000). The mystery of capital: Why capitalism triumphs in the west and fails everywhere Else. New York: Basic Books.

Eoin, W. (2005). The informal sector and micro finance institutions in West Africa. World Bank Regional and Sectoral Studies. Washington D.C.

Fantahun, M. (2000). Informal financial institutions: Impact analysis of ACORD`s credit intervention through Iddirs in Dire Dawa, (Masters Thesis).

Getachew, T., \& Yishak, M. (2005). Integrating financial services into the poverty reduction strategy: The case of Ethiopia paper presented at The East Africa Sub-Regional Workshop, June 28-30, 2006, Dares Salaam, Tanzania.

Ghatak, M., \& Guinnane, T. W. (1999). The economics of lending with joint liability: Theory and practice. Journal of Development Economics, 60(1), 195-228.

Gidey, G. G. (2011). Assessment of Financial and Operating Performance: A case study on DECSI, (Masters Thesis), Mekelle University, Mekelle, Ethiopia.

Godquin, M. (2004). Microfinance repayment performance in Bangladesh: How to improve the allocation of loans by MFIs. World Development, 32(11), 1909-1926

Gonzalez-Vega, C. (2008). Microfinance: Broader achievements and new challenges. Economics and Sociology occasional Paper No. 2518. Ohio State University.

Grameen Bank. (2000). Creating world without Poverty: Social business and the future capitalism, public affairs, New York.

Gujarati, D. N. (2004). Basic Econometrics, (4th Ed.). McGraw-Hill companies.

Guush, B. T. (2004). Risk matching behavior in credit group formation and implications for repayment: Evidence from Tigary, (Masters Thesis), Wageningen University, Netherlands.

Hunte, C. K. (1996). Controlling loan default and improving the lending technology in credit institutions. Saving and Development, Quarterly Review, 1:45-59.

International Fund for Agricultural Development. (2001). Ethiopia: Rural financial intermediation program (RUFIP). Appraisal Report Working Paper 1: The microfinance sub-sector.

Jama, M. A., \& Kulundu, D. M. (1992). Small holder farmer's credit repayment performance in Lugari division, Kaka Mega, Kenya. East African Economic Review, 8(2), 85-91.

Jemal, A. (2003). Microfinance and loan repayment performance: Case Study of the Oromia Credit and Savings Share Company (OCSSCO) in Kuyu, (Maters Thesis), Addis Ababa University, Addis Ababa, Ethiopia.

Kalleberg, A. L., \& Leicht, K. T. (1991). Gender and organizational performance: Determinants of small business survival and success. Academy of Management Journal, 34(1): 136-161.

Karlan, D. S. (2007). Microfinance impact assessments: The perils of using new members as a control group. Journal of Developing Economies, 3.

Kashuliza, A. (1993). Loan repayment and its determinants in smallholder agriculture: A case study in the Southern Highlands of Tanzania. East Africa Review, 9(1).

Kassa, W. (1998). Impact analysis of southern Ethiopia microenterprise project on beneficiaries social and economic Conditions. Paper presented to The National Microenterprise Project Workshop, (Amharic Version), June 9-11, Addis Ababa. 
Ledgerwood, J. (1999). Sustainable banking with the poor microfinance handbook: An Institutional and Financial Perspective, the World Bank, Washington, DC.

Manohar, S., \& Zeller, M. (1997). Repayment performance in group-based credit programs in Bangladesh: An empirical analysis. World Development, 25(10), 1731-1742.

Mead, D. C., \& Liedholm, C. (1998). Dynamics of micro and small enterprises in developing countries. Journal of World Development, 26(1), 61-74.

Mekelle City Plan Preparation Project Office (MCPPPO). (2005). Interim unpublished report.

Mekelle Municipality. (2002). Population survey conducted by the municipality, statistical report.

Meklit Microfinance Institution, Progynist, \& Alisei NGO. (2004). Trends, challenges and other key issues in micro finance development in Ethiopia.

Mekonnen, Y. (2004). Amhara credit and saving institution (ACSI): Institutional profile, current status and future strategy, Bahir Dar, Ethiopia.

Mengistu, B. (1997). Determinants of micro enterprises loan repayment and efficiency of screening mechanisms in urban Ethiopia: The case of Bahir Dar and Awassa town. Addis Ababa University.

Mengistu, B. (1999). Determinants of industrial loan repayment in Ethiopia: The case of manufacturing firms in Addis Ababa, Proceedings of the 8th Annual Conference on Ethiopian Economy, 117-132.

Michel, A., \& Sarpong, A. (2011). The gender side of lending: Are females better borrowers. Economics and Finance Review, 1(3), 46-50.

Micka'el, A. (1996). Micro-finance repayment problems in the informal sector in Addis Ababa. Ethiopian Journal of Business and Development, 1(2).

Miller, L. F. (1977). Agricultural credit \&finance in Africa. The Rockefeller foundation, USA.

Njoku, J. E., \& Odii, M. A. (1999). Determinants of loan repayment under the special emergency loan scheme (SEALS) in Nigeria: A case study in Imo State. African Review of Money Finance and Banking, 1, 39-51.

Norhaziah, N., \& Mohdnoor, M. (2010). Determinants of repayment performance in microcredit Programs. International Journal of Business and Social Science, 1(2).

Okorie, A. (1986). Major determinants of agricultural small holder loan repayment in a developing economy: Empirical evidence from Ondo State, Nigeria. Savings and Development, 1, 89-98.

Padmanabhan, K. P. (1981). Hedging loan delinquency in rural credit projects: Lessons from Indian experience. Savings and Development journal, 4, 263-270.

Ramu, A. H. (2011). Repayment performance of Grameen bank borrowers: The unzipped state. Savings and Development, 4, 451-473.

Retta, G. (2000). Women and micro finance: The case of women fuel wood carriers in Addis Ababa, (Master Thesis), Addis Ababa University, Addis Ababa.

Robinson, M. (2002). The microfinance revolution: Sustainable banking for the poor, Washington, DC. World Bank.

Roslan, A. H., \& Mohd, Z. A. (2009). Determinants of micro credit repayment in Malaysia: The case of Agro bank. Journal of Humanity and social sciences, 4(1), 45-52.

Seifu, A. (2002). The demand for micro credit services in the Afar National Regional State. The case of Gewane Woreda. (Master Thesis). Department of RLDS.

Stearns, K. (1995). The hidden beast: Delinquency in micro enterprises credit program. ACCION discussion document No. 6.

Stiglitz, J. E. (1993). Peer monitoring and credit market in the economics of rural organization: Theory, practice and policy. World Bank, Oxford University Press.

Teferri, Z. (2000). Micro finance and the poor: The case of Dedebit Credit and Saving Institution (DECSI) in Tigray, (Masters Thesis), Addis Ababa University, Addis Ababa.

Ugbomeh, G. M., Achoja, F.O., Ideh, V., \& Ofuoku, A. U. (2008). Determinants of loan repayment performance among women self help groups in Bayelsa State, Nigeria. Agriculture Conspectus Scientificus, 73(3), 189195.

Varian, H. (1990). Monitoring agents with other agents. Journal of Institutional and Theoretical Economics 146, 153-174.

Vigano, L. (1993). Credit scoring model for development banks: An African case study. Savings and Development, 17(4), 441-482.

Von Pischke, J. D. (1991). Finance at the frontier: Debt capacity and the role of credit in the private economy. EDI Development Studies. The World Bank, Washington D.C.

Woller, G., \& Woodworth, W. (2001). Microcredit as a grass-roots policy for international development. Policy Studies Journal, 29 (2).

Yesuf, L. (2010). Performance evaluation of the commercial bank of Ethiopia: Pre and post liberalization, (Master Thesis), Mekelle University, Mekelle.

Yunus, M., (1999). Banker to the poor micro-lending and the battle against world Poverty, New York. 
Zeller, M. (1996). Determinants of repayment performance in credit groups: The role of program design, intragroup risk pooling and social cohesion. Economic Development and Cultural Change, 46(3), 599-621. 